\title{
The Weaponisation of the Coronavirus Crisis in Zimbabwe: Legal and Extra-Legal Instruments
}

\author{
Gorden Moyo', Kucaca Ivumile Phulu² \\ ${ }^{1}$ Faculty of Social Sciences and Humanities, Lupane State University, Bulawayo, Zimbabwe \\ ${ }^{2}$ Faculty of Public Law, University of South Africa, Pretoria, South Africa \\ Email: gordenmoyo@gmail.com, kiphulu@gmail.com
}

How to cite this paper: Moyo, G., \& Phulu, K. I. (2021). The Weaponisation of the Coronavirus Crisis in Zimbabwe: Legal and Extra-Legal Instruments. iBusiness, 13, 48-66.

https://doi.org/10.4236/ib.2021.131004

Received: January 4, 2021

Accepted: March 22, 2021

Published: March 25, 2021

Copyright (c) 2021 by author(s) and Scientific Research Publishing Inc. This work is licensed under the Creative Commons Attribution International License (CC BY 4.0).

http://creativecommons.org/licenses/by/4.0/

(c) (i) Open Access

\begin{abstract}
This article sets out to examine the legal and extra-legal instruments deployed by the ruling executive-military alliance in the fight against the scourge of the COVID-19 pandemic in Zimbabwe. The ruling executive-military alliance led by President Emmerson Mnangagwa has responded to the eruption of the coronavirus by adopting a highly securitised approach backed by a battery of legal and extra-legal instruments. It is therefore the argument of this article that the Mnangagwa administration has weaponised COVID-19 in order to achieve some objectives beyond the public health concerns. In particular, the government has sought to use the lockdown measures to clamp down on political opposition, silence critics, contain the restive population, and entrench its power and control over some key accountability institutions including the legislature, the judiciary, and the media. The article concludes by canvassing for the de-securitisation and de-weaponisation of COVID-19. This means shifting the concept of securitisation of public health threat from a state-centred focus that privileges government and state security apparatuses to one that accentuates people as the main beneficiaries of the fight against this deadly coronavirus pandemic.
\end{abstract}

\section{Keywords}

COVID-19, De-Weaponisation, Securitisation, Weaponisation, Zimbabwe

\section{Introduction}

The coronavirus pathogens landed on the shores of Zimbabwe on the back of a country whose government was battling with political legitimacy, the worst economic turmoil in recent years, and a politically restive population. Like the rest of the governments spanning the globe, Harare responded to the outbreak of the COVID-19 pandemic by banning air travel, closing borders, schools, univer- 
sities, colleges, religious gatherings, sporting events, and nightclubs as well as enforcing social distancing, mask wearing, and stay-at-home orders among other lockdown measures. More importantly, the government of Zimbabwe deployed the state security services to enforce intrusive lockdown measures. This deployment has been justified by government as being necessary to prevent violations of provisions and regulations of the COVID-19 Regulations (Ministry of Health and Child Care, 2020a).

As at 13 December 2020, the country had recorded 11,219 total accumulative positive cases of coronavirus infections, 9359 recoveries, and 307 deaths (Ministry of Health and Child Care, 2020b). Although the lockdown orders were ostensibly issued to curb the spread of the pandemic, it is the argument of this article that the COVID-19 crisis has offered a convenient cover for the ruling elite to clamp down on political opposition, silence critics, contain the restive population, and entrench its power and control over some of the key accountability institutions including the legislature, the judiciary, independent media, and civil society among others (Ganjanakhundee, 2020). This article therefore analyses how legal instruments, state security apparatuses, and COVID-19 relief measures have been deployed as political instruments to achieve some goals beyond the containment of public health crisis in Zimbabwe.

It is worth noting from the outset that Zimbabwe is currently ruled by a cabal of a military-executive alliance led by President Emmerson Mnangagwa who took over power through a coup de tat in November 2017. The Mnangagwa government is dominated by former military generals including the former Commander of the Defence Forces Constantino Chiwenga, now the Vice President; the former Air Marshal Perence Shiri, now the Minister of Lands and Agriculture; and the coup-announcer General Sibusiso Moyo now the Minister of Foreign Affairs. Since taking over the reins of power in 2017, the Mnangagwa-administration has been battling with a melange of structural and systemic problems including high levels of poverty, unemployment, and a full-blown economic recession among others. The majority of Zimbabweans who initially supported the ousting of Robert Mugabe by the military are now agitated by government's ineptitude and failure to address the economic crisis. In this context, the ruling executive-military alliance has resorted to state security apparatuses to keep the agitated public at abeyance.

As such, there are claims that the coronavirus crisis has provided the ruling executive-military alliance with the opportunity to deal with its political problems under the pretext of combating the deadly coronavirus. There is hardly any doubt that in public health emergencies there is a reasonable basis for the inclusion of the security sector in response efforts (Adayaalam Centre for Policy Research, 2020), however, it is imperative to examine its activities given its embedded role in the governance structures of the country. This also entails assessing the legal framework that underpins the response to the COVID-19 pandemic in Zimbabwe. The article draws on a range of primary data collected through key informant interviews with political leaders, civil society actors, academics, cen- 
tral intelligence community, government officials, and members of parliament. To respect the anonymity of these individuals, the interviews were held off record. The authors also made use of online sources, government publications and press reports.

The article is structured as follows: Section 2 presents the securitisation paradigm as the basis of the weaponisation of COVID-19 in Zimbabwe; Section 3 examines the legal and extra-legal instruments that provided the cover for the weaponisation of the pandemic; Section 4 discusses the weaponisation of the COVID-19 relief programmes; Section 5 draws attention to need for de-securitisation and de-weaponisation of the coronavirus crisis while Section 6 sums up the arguments and the prospects for the future.

\section{Weaponisation of COVID-19}

It is common cause that the fight against the coronavirus pandemic has taken a highly securitised approach in most countries across the globe. This has partly been occasioned by the World Health Organisation which provided the "securitised speech" on 11 March 2020 when it declared the COVID-19 a global health pandemic and asked governments across the globe to take measures against it (World Health Organisation, 2020). As per the Copenhagen school, the framing of the coronavirus by the World Health Organisation as an existential threat elevated the pandemic beyond the level of everyday politics thereby justifying the adoption of emergency measures by national governments (Hoffman, 2020). Unsurprisingly, the declaration triggered the endorsement of a slew of securitised national responses against the global pandemic including the suspension of normal constitutional procedures through state of emergency (Clifford, Owen, \& Harrison, 2020). The common measures taken by governments across the globe include air, sea and land travel restrictions; isolation of foreigners and returning nationals; enforcement of stay-at-home orders, and the lockdown on public spaces, schools, colleges, universities, non-essential services as well as religious, sporting and social events centres.

However, emerging evidence indicates that although the securitisation of public health can be a useful tactic for generating interests, resources, and urgency towards containing the pandemic, there are a myriad of problems associated with ultra-securitisation of the public health threat. For example, in countries such as China, Egypt, Ethiopia, Hungary, Niger, Nigeria, and Poland, the state of emergencies have been repurposed for numerous agendas, including increasing social and political control of the population beyond public health concerns (Geneva Centre for Security Governance, 2020). The repurposing of the fight against coronavirus crisis for goals other than public health is defined in this article as the weaponisation of COVID-19. With respect to Zimbabwe, it will be argued that the ruling executive-military alliance has weaponised the fight against the coronavirus pandemic through deploying state security services backed by a battery of legal and extra-legal instruments as weapons used for neutering political dissent, sidelining of parliament and the judiciary services, arresting and detaining journal- 
ists and civil society leaders among others (Beiber, 2020).

There is hardly any debate about the fact that Zimbabwe is a highly militarised state (Moyo, 2016). While the military has always been influential in Zimbabwe, it has however expanded its footprint in the economy, parastatals, state-enterprises, parliament, and cabinet following the exit of Robert Mugabe in November 2017. It is therefore hardly surprising that the Zimbabwe government deployed the armed security forces prominently to enforce the COVID-19 lockdown measures, as it has more soldiers and police officers than professional health workers. Available records show that Zimbabwe has an average of 45,000 police officers and 35,000 soldiers against a paltry 13,500 number of nurses and doctors (Global Firepower, 2020).

Observably, the ruling executive-alliance which came to power on the back of a military coup is ultra-sensitive to criticism and public dissent (Ndimande and Moyo, 2018). As one key informant interviewed for this article noted, "under its rule, critics of government, the opposition leaders, and the human rights champions are viewed as security threats that should be 'liquidated' together with the coronavirus pathogens". Of particular concern to the military-dominated government of Zimbabwe is that the opposition has refused to recognise President Mnangagwa who is accused of doctoring the 2018 presidential election results. Thus, since 2018, the opposition has been claiming that Emmerson Mnangagwa is an illegitimate President. Subsequently, there has been a constant threat of mass demonstration against him and his government which has kept the security services sector on high alert.

Added to this problem is the fact that the arrival of the coronavirus coincided with the country's worst economic turmoil in recent years. In particular, the virus landed on the back of Cyclone Idai which left over 270,000 people homeless in 2019, devastating drought which has seen 8.5 million people being food insecure in a population of 16 million, and an unsustainable sovereign debt burden of over US\$20 billion (Moyo, 2020). As such, the country is currently engrossed in a debilitating debt trap, shortages of power, cash and portable water in most of the urban areas. Moreover, over 80 percent of Zimbabweans are in the informal sector and have had their access to livelihoods, health care, food and water severely restricted by the lockdown measures (ZIMCODD, 2020).

In the wake of these dynamics, this analysis notes that the ruling executive-military alliance has sort to capitalise on the context of the coronavirus crisis to manage its economic and political problems. As will be demonstrated in the following section, the ruling executive-alliance led by President Mnangagwa has weaponised a battery of legal and extra-legal instruments in the name of combating COVID-19 pandemic to clamp down on opposition members, journalists, civil society activists, and to attenuate the restive population in Zimbabwe.

\section{Legal and Extra-Legal Instruments}

\subsection{Manipulation of Legal Instruments}

The institutional setup for fighting the coronavirus pandemic was established on 
19 March, 2020 with a decision by government to declare a State of National Disaster in terms of the Civil Protection Act of 1989. Subsequent to this declaration, the Minister of Health and Child Care issued the Public Health Order, 2020 (Statutory Instrument 83 of 2020). Over and above this legal framework, government also issued a dozen of other Statutory Instruments as part of the containment measures. Notably, all of these instruments were issued by the executive arm of the state without consulting parliament and other stakeholders. It is in fact interesting to note that since coming to power in November 2017, the Mnangagwa-administration has issued more Institutional Instruments than Robert Mugabe issued in his entire 37 years of reign. Essentially, the executive-military alliance led by Mnangagwa has appropriated to itself the power to legislate by announcements. This is despite the fact that the ruling party-the Zimbabwe African Union-Patriotic Front (ZANU PF) controls the legislature and can easily pass any bill into law with very little resistance from the opposition.

The following provides a snapshot of some of the Statutory Instruments that have been issued to affect the COVID-19 Lockdown measures without any parliamentary role:

- Public Health (COVID-19 Prevention, Containment and Treatment) Regulations, 2020 (published as Statutory Instrument 77 of 2020) consolidated as at 12 June 2020.

- Public Health (COVID-19 Prevention, Containment and Treatment) (National Lockdown) Order, 2020 (Statutory Instrument 83 of 2020) as amended by: SI 84/2020; SI 86/2020; SI 93/2020; SI 94/2020; SI 99/2020; SI 101/2020; SI 102/2020; SI 110/2020; SI 115/2020.

- SI 2020-096 Presidential Powers (Temporary Measures) (Deferral of Rent and Mortgage Payments During National Lockdown) Regulations, 2020 Consolidated (12 June, 2020).

- Civil Protection (Declaration of State of Disaster: Rural and Urban Areas of Zimbabwe) (COVID-19) Notice, 2020 SI 76/2020.

- Public Health (COVID-19 Prevention, Containment and Treatment) (National Lockdown) (Amendment) Order, 2020 (No. 14).

As noted above, none of these Statutory Instruments were presented to parliament and yet they give very wide powers to the executive arm of the state to execute a fight against the coronavirus crisis. While, there is no doubt that some of these powers are necessary to deal with the virus and mirror those adopted in democratic jurisdictions, the problem is that their use is not restrained by the checks and balances that should be offered by parliament as will be explained anon. In addition, some constitutional experts have argued that the powers contained in some of the Statutory Instruments go beyond the parameters of a declaration of a State of National Disaster as they infringe on the constitutionally provided social, economic, and cultural rights as well as political and civil liberties of Zimbabweans (Magaisa, 2020). While the Constitution of Zimbabwe authorises the government to issue Statutory Instruments in case of urgency and 
emergency, the same Constitution provides for the role of parliament for the sake of checks and balances as well as accountability and democratic governance.

It is important to mention at this point that the Zimbabwe government has not formally invoked a state of emergency in the country as stipulated in section 87 (1) of the Constitution (Amendment [No. 20] Act 2013. And yet, its behaviour together with that of the security services is that of a government that is in a state of emergency. Clearly, the executive-military cabal has manipulated the Statutory Instruments to eschew having to forgo the state of emergency route. To be clear, the executive-military alliance has avoided declaring a state of emergency and yet it exercises powers as near as possible to the emergency powers, without the onerous checks and balances. In the process, parliament has been sidelined, journalists have been arrested and harassed, and the opposition leaders have been treated with indignity. In short, Zimbabwe is in a de facto state of emergency.

With total disregard of the constitution, on 21 July 2020, President Mnangagwa issued additional measures ostensibly to further tighten the fight against the emerging spike of virus infections. The additional measures mainly consist of a curfew that runs from 6 o'clock in the evening to 6 o'clock in the morning. The stated purpose of the curfew to prevent transmission of the virus within communities is a welcome goal. However, the way in which the curfew has been administered has raised serious questions about whether it is achieving its purpose. In particular, the failure to put in place government support prior to declaring a curfew has disproportionately impacted the economically marginalised sections of society who rely on street trading, vending, and hawking. And more curiously, the declaration of the curfew coincided with the call by civil society and opposition parties for a demonstration against the worsening economic conditions and against the endemic corruption including the corruption associated with COVID-19 resources.

The said demonstration was scheduled for the $31^{\text {st }}$ of July 2020 . It can be hardly doubted that the additional lockdown enforcement measures announced by the President 10 days before the planned day of the demonstration were also meant to pre-empty the demonstration apart from attempting to flatten the rising coronavirus infection curve. More strikingly, one of the organizers of the planned demonstrations Pastor Jacob Ngarivhume was arrested a few days after the promulgation of the lockdown curfew (Pindula News, 2020a). It cannot be further from the truth that government has weaponised the fight to combat COVID-19 and used it to pre-emptively undercut the constitutional right of the people of Zimbabwe to peacefully demonstrate against corruption in the country.

In short, the ruling executive-military alliance has approached the coronavirus crisis with security lenses. It has sort to manipulate the legal instruments as weapons to handle its political opponents over and above combating the global pandemic. It has preferred exercising special executive powers to following normal parliamentary process. However, the imposition of restrictive measures 
even for right reason, not backed by law might set a precedent where the executive might be emboldened to impose its will upon the people as it will be used to side stepping the constitution.

\subsection{Emasculation of the Legislature}

Following the imposition of the lockdown measures, the ruling party-controlled parliament suspended its regular sessions on 5 May 2020 (Parliament of Zimbabwe, 2020). Some observers posit that this was conveniently done without putting in place any regulations or standing orders to allow for its operations during the lock down period. To be sure, Statutory Instrument 77 of 2020 which provides for the COVID-19 Prevention, Containment and Treatment Regulations and all its subsequent amendments, does not include parliament as among the institutions that are exempt from the movement restrictions it imposes.

In practical terms, this means that parliament was technically hamstrung from performing its oversight duties during the initial phase of the lockdown. And yet, in terms of section 139 of the Constitution (Amendment [No. 20] Act 2013), it was up to parliament to put in place, using its power to make Standing Orders, regulations to allow for its operations during the lockdown period. Although the failure on the part of parliament to act cannot on the face of it directly be placed on the door of the executive, there are compelling circumstances pointing to parliament's lack of independence and the strangle-hold that the executive has on parliament which allows for a plausible conclusion that there was in fact a gag, imposed politically on parliament during this period (Veritas, 2020a). The disablement of parliament's oversight was certainly taken advantage of by the executive who over reached on their powers.

Instructively, while inactive on matters of accountability, it is important to note that parliament sprang into action to effect what has been perceived as an attack on the opposition by being complicit in the recalling of opposition Members of parliament following the Supreme Court Judgement on the case of the opposition intra-party squabbles pitting Mashavira vs MDC (Movement for Democratic Change). To be sure, on 5th May, 2020 both the National Assembly and the Senate met in reduced numbers for the first time during the COVID 19 lockdown. A close assessment of the Parliamentary Order Paper indicates that there was nothing compelling on the agenda except the announcements by the presiding officers notifying the expulsion of four opposition members of parliament in terms of Section 129 (1) (k) of the Constitution of Zimbabwe (Veritas, 2020b). Again, on Tuesday 23rd June, 2020 the speaker of parliament announced the expulsion of nine more opposition members of parliament belonging to one of the factions of the opposition Movement for Democratic Party which is viewed as intrusive by ZANU PF government (Veritas, 2020b).

As intimated earlier, the opposition members of parliament have hotly contested the legitimacy of the President of Zimbabwe following the 2018 disputed presidential election. What is questionable in this context is the sudden awaken- 
ing of the speaker of parliament from his previously supine position, to open parliament so as to facilitate the expulsion of the opposition members of parliament that questioned the legitimacy of the President. A key informant interviewed for this paper noted that the challenge on the legitimacy of the President has been the reason for the heavy handedness by the executive over the opposition members of parliament as exemplified by their dismissals, ejectments, and recalls under the watch of a pliant speaker of parliament. The failure by parliament to move quickly to provide mechanisms to address the oversight lacuna during the COVID-19 lockdown, while being able to interfere with opposition intra-political party matters is evidence of its susceptibility to being wielded as a political weapon for executive agendas.

\subsection{Tethering with the Judiciary}

The above notwithstanding, the judiciary, unlike parliament, was able to control its own processes regarding its internal regulation of the lockdown. For example, it was able to regulate its own response to the COVID-19 crisis by making its own directives allowing limited movement of its members including legal practitioners as well as the operations of its courts (Malaba, 2020). This assertion by the judiciary of its turf, saw the eventual passing of Amendments to COVID-19 Lock-down Order (SI 83 of 2020) by Order No. 12 (SI 153 of 2020) to recognise the Judiciary as an essential service. However, beyond this positive aspect, the judiciary did not escape the tentacles of executive influence either directly or indirectly. The handing down of the Supreme Court Judgement in the case of Mashavira v MDC and Others (2020) on 31 March, 2020 referred to earlier, is curious example of the court passing a judgement that politically weakens the opposition while strengthening the ruling party at the height of the COVID-19 lockdown. The judgement is now sarcastically referred to as the "Coronavirus Judgement" by some members of the public.

On another note, and of particular concern is that, despite the gravity of the coronavirus crisis, the Mnangagwa-administration has taken advantage of the lockdown to change the manner in which the nation's top judges are appointed. To be clear, five vacancies have existed in the Constitutional Court since 22nd May, 2020. These vacancies have arisen due to the expiry of the temporary transitional constitutional provisions under which Supreme Court judges also served as Constitutional Court judges for the first seven years of the court's existence in terms of paragraph 18 (2) of the Sixth Schedule to the Constitution (Act no 20 2013). Friday 22nd May, 2020 was the date when the seven years came to an end (Veritas, 2020c). The procedure to appoint the judges involves the appointment powers of the President being subject to interviews by the Judicial Services Commission, and picking from a list provided by the Judicial Services Commission.

However, the executive has now put forward Constitutional Amendment number 2 which inter alia seeks to amend the Constitution to permit the President to directly appoint the Constitutional Court judges, hence consolidate the 
power of the President while weakening the Judiciary in the process. The public Consultation process for Constitutional Amendment number 2 has been rushed through despite the fact that members of the public are currently under lockdown and cannot participate effectively in this important process.

Overall, the executive has used lockdown legal and extra-legal instruments to further its influence over the judiciary and legislative branches of the state. Thus, while the government has been heavily engaged in managing the coronavirus crisis, it has also been sending contradictory messages through its political actions that have further intensified political polarisation at a time when social cohesion was a critical factor in combating the deadly coronavirus. Moreover, the legal and extra-legal instruments adopted by the ZANU PF-led government have violated human rights and basic freedoms, including the right to liberty, freedom of association, and freedom of movement as will be explained anon.

\section{Abuse of Human Rights and Threats to Independent Media}

The emerging evidence indicates that the ruling executive-military alliance's response to the pandemic has continuously disregarded human rights and presents worrying implications for the already traumatised peoples of Zimbabwe as will be explained anon. While the Mnangagwa administration has styled itself as the Second Republic that has taken a break from the Mugabe regime that was infamous for impunity, the emerging evidence indicates that rights protected by the Constitution such as the right to human dignity, right to personal security, right to freedom from torture, cruel inhuman or degrading treatment, freedom of assembly and association, the right to demonstrate and petition, freedom of conscience, freedom of expression and freedom of the media as well as the right to development were bluntly violated by the members of the security forces deployed to enforce the lockdown measures (Kucaca and Kamga, 2019). This has led the United Nations Commission for Human Rights through its spokesperson Liz Throssell to express concern over the human rights situation in Zimbabwe. She is reported saying that "we are concerned at allegations in Zimbabwe, which suggest that the authorities may be using the COVID-19 pandemic as a pretext to clamp down on freedom of expression and freedom of peaceful assembly and association" (Pindula News, 2020b).

There have been numerous reports about harassment and violence against the members of the public by the members of armed forces. As Mutambasere (2020) observed, the police had reportedly assaulted 10 people in different parts of the country for violating the lockdown rules within two days of the announcement of the lockdown. In most of Zimbabwe's cities and towns, armed soldiers and members of the police have detained several people and beat up those who questioned their motive in blocking them from accessing cash in banks and buying food supplies. Even nurses and doctors who staged a peaceful demonstration against low salaries and lack of protective equipment were beaten up and ar- 
rested by state securities. To be precise, the state security services have arrested over 100,000 people for allegedly violating the lockdown regulations (Africa News, 2020). Clearly, the broad granting of arresting powers to the police and military is extremely concerning, especially given the systemic violence displayed by these institutions towards the members of the public, opposition, civil society, and independent media.

In this context, women have been disproportionately affected by the weaponisation of lockdowns. The case in point was the abduction, torture and subsequent arrest of an opposition member of parliament Joanna Mamombe, Cecilia Chimbiri, and Netsai Marova who dared demonstrate against corruption in Harare. Similarly, on April 16, 2020 in Bulawayotwo sisters namely; Nokuthula and Ntombizodwa Mpofu were handcuffed, assaulted, labelled "prostitutes" and tribally insulted by police officers after they had gone to the shops to buy some foodstuffs (Catholic Justice for Peace, 2020). These examples are indicative of a widespread problem of violation of human rights and particularly that of women by the uniformed forces purporting to be enforcing the lockdown measures. Women organisations, civil society and opposition political parties are understandably correct to be concerned about the broad arresting powers that have been given to state security services having borne the brunt of widespread human rights violations from the security services for decades.

In the same vein, the media has also found it difficult to operate in these circumstances as the lockdown is securocentric allowing the securocrats to exercise their power in a capricious wanton and erratic manner. The Mnangagwa-administration has detained not only opposition activists but also journalists. For example, three journalists were arrested and charged with breaking the lockdown regulations while attempting to report on the case of the three opposition activists Joana Mamombe and her two colleagues referred to earlier (Kagurume, 2020). The Media Institute of Southern Africa also reported that Freelance journalist Terence Sipuma was on 11 April 2020 assaulted by members of the police and the army in Harare while on his way to Chegutu to report on Zimbabwe's 21-day COVID-19 lockdown (Media Institute of Southern Africa, 2020). Additionally, an award winning journalist Hopewell Chin'ono was abducted from his house in Harare on 20 July 2020 by 8 police officers and charged with inciting public violence after he twitted his support for nationwide protests against government corruption and worsening economic (Media Institute of Southern Africa, 2020). Apparently, Hopewell Chin'ono is an investigative journalist who wrote a story about corruption associated with COVID-19 which implicated President Mnangagwa's family. To Chin'ono's credit, the Minister of Health and Child Care Obadiah Moyo who was implicated in the scandal has since been arrested and expelled from Cabinet.

In the effort to clamp down on the independent media and social media, the Mnangagwa-administration has passed a decree that allows the police to fine or imprison those deemed to be spreading "fake news" critical of official management of the pandemic. As section on COVID-19 Regulations reads as follows: 
"For the avoidance of doubt any person who publishes or communicates false news about any public officer, official or enforcement involved with enforcing or implementing the national lockdown in his or her capacity as such, or about any private individual that has the effect of prejudicing the State's enforcement of the national lockdown, shall be liable for prosecution under Section 31 of the Criminal Law Code and liable to the penalty there provided, that is to say a fine of up to or exceeding level fourteen or imprisonment for a period not exceeding twenty years or both" (Ministry of Health and Child Care, 2020a).

In Zimbabwe where the state security services have consistently used intimidation and harassment of human rights defenders, journalists, and political opponents as tools of political control, the broad powers being given to them without oversight or end date is of grave concern. There is no denying that curbing malicious misinformation about the pandemic is a worthwhile endeavour; however, the arbitrariness of the way this power is being used suggests this is an opportunistic attempt to emasculate public debate, social accountability and legal opposition in the country. To further toughen its grip on the media, the ruling executive-alliance has gazetted a Cyber Security and Data Protection Bill. While the proposed Bill seeks to curb financial crimes and other cyber related illicit deals, once passed into law it would also empower government to perform unlimited surveillance on all citizen communication while banning the distribution of any information it chooses (Roth, 2020). By so doing, the executive-alliance has sort to assert its power over media and other information and accountability institutions undercover of fighting the coronavirus pandemic.

\section{Suspension of the Elections}

The electoral processes have not been spared from the political expedients prosecuted under the veil of containing the public health crisis. On 25 March, 2020, the Zimbabwe Electoral Commission (ZEC) suspended all electoral activities in including council and parliamentary plebiscites. In suspending these processes, the electoral management body noted that its action was in line with the lockdown orders. However, in a document entitled, Suspension of Electoral Activities argues that the suspension of the elections was unlawful as there is nothing in the constitution permitting the electoral management body to suspend elections of its own accord (Veritas, 2020c). Veritas further contends that, elections cannot, in terms of the constitution be suspended on the basis of the COVID-19 measures which consist of and large of regulations passed by the executive without the involvement of parliament which is constitutionally charged with the responsibility of making laws in Zimbabwe. In particular, Section 13 (1) (a) of the constitution does not allow the executive to usurp parliament's primary law-making power.

Some key informants interviewed for this paper have claimed that ZEC has long been captured by the ruling executive-military alliance. They pointed out 
that whatever proclamations are made by ZEC reflect the mind of the executive rather the mind of the electoral body. This runs against the grain of the independence of ZEC as provided in the Constitution. Veritas (2020c) also rightly observes that the announcement to suspend elections was not followed up with an official notice in the Gazette or a newspaper. It was therefore a classic unilateral boardroom decision not suitable for as important an issue as national elections. While, it is understandable that given the lockdown and the massive public health scare, suspension of elections could be justifiable, nonetheless, it must be borne in mind that there was no consultation with the stakeholders leaving the move susceptible to being seen as the ruling party taking advantage of the lockdown measures to leverage the electoral landscape to its own advantage (Zimbabwe Election Support Network, 2020).

More contentiously, the fact that the members of parliament could be expelled from parliament without providing mechanisms of allowing the filling in of the vacancies so created gives credence to the claim that the suspension of the electoral processes is part of the weaponisation of the fight against COVID-19. This assertion is further bolstered by the fact that parliament in the meantime, did not in the same vein put a moratorium of creating more vacancies by recalling members of parliament. One key informant interviewed for this article was probably right when she noted that ZANU PF government which controls parliament has become tired of opposition voices challenging the legitimacy of President Mnangagwa in a space which should ordinarily reflect the strength of the ruling party.

Lastly, one has to consider the fact that in Malawi, the incumbent made an attempt to stop the then imminent elections by putting in place a 21-day lockdown. The opposition as well as civil society criticized the then President of Malawi Peter Mutharika's response to the pandemic, calling it inadequate and aimed at keeping him in power, basically a weaponisation of COVID-19 (Ellena, 2020). This led to a subsequent court challenge which struck down Mutharika's 21-day lockdown paving way for the election to take place. More importantly, the opposition leader Lazarus Chakwera won a presidential election held amid the global coronavirus pandemic. This example demonstrates that it is critical to weigh the pros and cons of the COVID-19 responses against the integrity of the Constitution.

\section{Weaponisation of the Coronavirus Relief}

As explained earlier, the National Lockdown Regulations read together with the Public Health Act empower the Minister of Health and Child Care to mobilise and allocate adequate funding and other resources from public and private sources to combat the COVID-19 outbreak. In line with the regulations, government made a humanitarian call for US $\$ 2.2$ billion to respond to the urgent need to increase the number of beds in the health facilities nation-wide for isolation of suspects, confirmed and probable cases; increase availability of medical 
equipment including ventilators, patient monitors as well as medical supplies and consumables required for the management of cases; increase the availability of laboratory supplies and consumables; increase the availability of personal protective equipment for all health workers involved in the management of cases; increase the capacity to safely refer patients by ambulance (Office for the Coordination of Humanitarian Affairs, 2020).

In addition, on 30 April 2020, President Mnangagwa announced a US\$360 million COVID-19 Economic Recovery and Stimulus Package to cushion the private sector from the effects of the coronavirus crisis (Moyo, 2020). Apparently this is a huge package nearly 9 percent of GDP and 28.6 percent of Zimbabwe's 2020 National Budget (Moyo, 2020). A number of companies, individuals and countries such as China, the U.S., the UK, United Arab Emirates, and the EU among others have made some generous contributions towards the humanitarian call. Some of the donations are as follows:

- The EU: US\$45.5 million to Health Development Fund which is jointly managed by the UNICEF and the UNEFPA.

- US $\$ 25$ million from the Global Fund.

- US $\$ 5$ million from African Medallion Group.

- 100,000.00 Pounds donation of protective equipment to Wilkins Hospital from the Department for International Development (DFID, UK).

- US\$470,000.00 from the United States Agency for International Development (USAID).

- US\$7 million grant from the World Bank Group.

- 10,000 litres of hand sanitizers for hospitals nationally, knapsack sprayers and 15,000 tonnes of disinfectants and 40,000 litres of diesel from the Green Fuel Fossil ZimBitumen World.

- Ecosure, a subsidiary of Zimbabwe mobile phone operator Econet offered the following: Personal protective equipment for all doctors and nurses; free transport for nurses and doctors to commute to work and in sanitised vehicles.

- An upgrade worth US\$5,000,000.00 to Harare's main COVID-19 centre, the Wilkins Infectious Disease Hospital.

- A donation of 50,000 masks, and 510 protective suits by 2 Chinese firms to the First Lady Auxillia Mnangagwa's charity orgainsation.

- Equipment including 166,000 face masks, 7600 protective suits, 20,000 test kits, 12,000 pairs of gloves and five ventilators from the Chinese Embassy.

- 20,000 test kits, 100,000 face masks and 10,000 protective suits and face shield from China's richest man Jack Ma.

- US\$3 million donation from China International Development Cooperation Agency to UNICEF Zimbabwe (see Moyo, 2020).

However, what is unsettling is that most contributions towards COVID-19 are made to the President at his State House with no publicly known monitoring and accountability mechanisms in place (Moyo, 2020). More, curiously some of the donations especially from Beijing earmarked for COVID-19 have been made 
to the President's wife who runs a charity organisation-the Angel Hope. As such, the First Lady Auxillia Mnangagwa has become one of the biggest providers of sanitizers, masks, food supplies and other coronavirus related materials across the country (Moyo, 2020). She is covered by the national television and state newspapers across the country making these donations. Some key informants interviewed for this article claim that this is part of the weaponisation of the COVID-19 relief. This is because the COVID-19 relief programme has been made to be identified with the President's family.

What is even more worrying is that the ruling party ZANU PF has made the protective masks part of its paraphernalia with the portrait of its President and with party symbols. The desperate people without masks to prevent the deadly coronavirus are compelled by their circumstances to accept the political party masks and the branded sanitizers. This is a clear case of weaponisation of COVID-19 relief in search of political advantage. Yet on the other side of the ledger, opposition members of parliament have been arrested for providing unbranded masks and food to their constituencies.

For example, the opposition member of parliament of Mutasa South Constituency, Regai Tsunga was arrested in Mutare by the police while he was donating mealie-meal to the vulnerable and less privileged members of his constituency (Moyo, 2020). And yet, the people who had come to receive food packages were wearing masks and practising social distancing. Similarly, Jasmine Toffa an opposition member of parliament was reportedly blocked by police from delivering mealie in Bulawayo on 16 April, 2020 (Harare.com, 2020). A key informant interviewed for this article noted that in Zimbabwe law enforcement activities are largely conducted without proper judgement as the people are arrested for handing out food and sanitisers to people in need, as police wrongly believe that such gatherings are used in mobilising against government.

Clearly, the Mnangagwa administration which is insecure about its own popularity and legitimacy has placed a high priority on projecting strength and control through the control of resources and food distribution to the poor and vulnerable. The idea is to project and consolidate power by controlling access to food and masks as well as many other requisite supplies through what has come to be known as coronavirus diplomacy. Gavin (2020) was right when he posited that the Mnangagwa government hopes to position itself as a messiah to the majority of Zimbabweans who have been cut off from their means of survival by lockdown measures intended to stop the spread of the coronavirus None of these actions have basis in law.

It is common cause that the enactment of the emergency measures that bypass accountability and oversight procedures has dramatically increased the risk of corruption in Zimbabwe (Youngs and Panculidze, 2020). It should be noted that so far, the Ministry of Health has failed to make public or to provide the public with the distribution matrix of the donations for COVID-19 despite the fact that some organisations such as Transparency International Zimbabwe have re- 
quested this information and even taken the Minister to Court over it. The failure by the Minister of Health to avail the distribution matrix of the donations for the COVID-19 is in breach of Section 31 of the Public Heat Act. It is therefore not entirely surprising that the Minister of Health, having failed to act in a manner that gives public confidence to his office, now stands accused of corruption and nepotism for illegally awarding a multi-million-dollar contract for medical equipment (Al Jazeera, 2020). The Minister has also lost his Cabinet post. However, many observers doubt that the Minister was going to be arrested and subsequently fired from Cabinet had it not been for the media reports and in particular the process of Hopewell Chin'ono as explained earlier.

\section{Going Forward}

As the country struggles to deal with an unprecedented global pandemic, it is imperative that the country chooses an approach that respects human rights in addressing this crisis. While the cases of coronavirus remain relatively low in Zimbabwe, the spectre of a spike remains very high. In this context, the de facto state of emergency is likely to be maintained for a very long while. It is the argument of this article that in these circumstances the associated measures including restrictions of movements, quarantines, and lockdowns should be de-weaponised and thus carried out in accordance with the Bill of Rights and other regional and international human rights norms. It is in the interest of all Zimbabwean that the fight against coronavirus is not used as a basis to target the critics of government, civil society, opposition politicians, media, and the ordinary people.

In particular, there must be robust mechanisms put in place by bipartisan members of parliament to enhance parliament's oversight capacity during the fight against the COVID-19 so as to mitigate abuse of rights and enhance accountability and transparency. Looking ahead, parliament must ensure that all allegations of human rights including abuse of power, arbitrary detention, and sexual and gender-based violence by law enforcement and military personnel perpetrated in the name of fighting coronavirus are effectively and promptly investigated with a view to putting an end to these violations and abuses (United Nations Human Rights Office, 2020). ACPR (2020) was right when it noted that the scrutiny of governmental action is imperative to ensure that measures taken during this public health emergency do not infringe unduly upon individual and collective rights in the short or long-term especially for those who are already vulnerable (Adayaalam Centre for Policy Research, 2020).

As the United Nations Human Rights Office (UNHRO) (2020) has counselled, government should provide timely and effective measures to support the enjoyment of core economic and social rights of the people affected by emergency restrictions, including through support for employment and livelihoods, housing, food, education, social protection and health, in order to enable them to comply with the emergency measures. In the same vein, government must ensure that 
stimulus packages and other responses to mitigate the economic impacts of the pandemic are people-centred and directed at the groups most affected by the loss of their livelihoods, such as informal and independent workers without access to social safety nets without discrimination on the basis of political affiliation, gender, sex, region, and ethnicity (United Nations Human Rights Office, 2020).

More crucially, government should establish an Independent COVID-19 National Fund Trust that will have the mandate of managing, administering, and reporting on all the resources collected and used for fighting the coronavirus in Zimbabwe. This will provide the much-needed public trust and confidence on the management of the COVID-19 resources (Moyo, 2020). A truly independent body will ensure that the resources towards the fight against the coronavirus pandemic are depoliticised and de-weaponised. In short, the measures to contain the outbreak of the coronavirus should be implemented in ways that do not stymie the oversight role of parliament and other accountability including the media and the civil society as well as the opposition activists.

Lastly, in the context of ultra-securitised fight against the public health pandemic more resources are likely to be allocated towards the deployment of state security services for the purposes of enforcement of COVID-19 regulations as well as containing the agitated public. However, this article contends that government should shift from its state-centric security approach and move towards a more human security approach which privileges the welfare of the poor and the vulnerable in situations of hardships such as the one that Zimbabwe currently finds itself in. In the final analysis, the need for state-security should not be achieved at the expense of human security.

\section{Conclusion}

It was noted in this article that although the securitisation of global pandemic can be a useful tactic for generating interests, resources, and urgency in mobilising preventive measures, there are a myriad of problems associated with it. In the case of Zimbabwe, it was argued that the fight against COVID-19 pandemic has provided a perfect pretext for the ruling executive-alliance to further its own political objectives through weaponising the lockdown measures to quash dissent, silence human rights defenders and opposition political actors. However, it is the conclusion of this article that silencing free speech, jailing peaceful dissenters, suppressing legislative oversight, and indefinitely suspending elections will do very little to protect public health, improve the livelihoods of millions of people or restore the economy in Zimbabwe. Instead, the Zimbabwe government should de-weaponise the fight against the coronavirus crisis. This means shifting the concept of securitisation of public health threat from a state-centred focus that privileges government and state security apparatuses to one that accentuates people as the main beneficiaries of the fight against this deadly coronavirus pandemic. Future research may be required to examine the specific role of the 
military in the fight against COVID-19 in Zimbabwe References.

\section{Conflicts of Interest}

The authors declare no conflicts of interest regarding the publication of this paper.

\section{References}

Adayaalam Centre for Policy Research (ACPR) (2020). Sri Lanka's Militarised Response Poses Grave Threats to Human Rights (p. 5). Situation Brief No. 3.

http://adayaalam.org/situation-brief-no-3-COVID-19-sri-lankas-militarised-responseposes-grave-threats-to-human-rights

Africa News (2020). Zimbabwe Arrests 100, 000 for Flouting Lockdown Rules-Police. https://www.africanews.com/2020/07/20/zimbabwe-arrests-100000-for-flouting-lockdo wn-rules-olice

Al Jazeera (2020). Zimbabwe Health Minister Obediah Moyo Sacked amid Graft Scandal. https://www.aljazeera.com/news/2020/07/zimbabwe-health-minister-obediah-moyo-sa cked-graft-scandal-200708070434612.html

Beiber, F. (2020). Authoritarianism in the Time of the Coronavirus: The Pandemic Offers Dictators and Democracies Alike-An Opportunity for Abuse. https://www.everycrsreport.com/reports/R46336.html

Catholic Justice for Peace (2020). Two Zimbabwean Journalists Charged with Violating COVID-19 Lockdown.

https://cpj.org/2020/06/two-zimbabwean-journalists-charged-with-violating-COVID-1 9-lockdown

Clifford, S., Owen, W., \& Harrison, M. (2020). A Turning Point, Securitisation, and Policing in the Context of COVID-19: Building a New Social Contract between State and Nation? Policing: A Journal of Policy and Practice, paaa021.

Constitution (Amendment [No. 20] Act 2013). Government of Zimbabwe: Harare.

Ellena, K. (2020). Legal Quagmire of Postponing or Modifying Elections. https://www.ifes.org/news/legal-quagmire-postponing-or-modifying-elections

Ganjanakhundee, S. (2020). COVID-19 in Thailand: The Securitisation of Non-Traditional Threat. Perspective, No. 51 (22 May, 2020), Issue: 2020. https://www.iseas.edu.sg/wp-content/uploads/2020/03/ISEAS_Perspective_2020_51.pdf

Gavin, M. (2020). The Politics of Food in the Time of COVID-19. https://www.cfr.org/blog/politics-food-time-COVID-19

Geneva Centre for Security Governance (2020). Security Sector Governance and Rule of Law Reform: States of Emergency during COVID-19 Response in Practice. Geneva: Geneva Centre for Security Sector Governance. https://www.files.ethz.ch/isn/100124/18_SSR_SSG_en.pdf

Global Firepower (2020). Active Military Manpower (2020): Total Available Active Military Manpower by Nation. Zimbabwe. https://www.globalfirepower.com/active-military-manpower.asp

Harare.com (2020). Harare: MDC MP Arrested While Donating Mealie-Meal to the Less Fortunate. https://iharare.com/tag/regai-tsunga-donates-mealie-meal

Hoffman, A. (2020). The Securitisation of the Coronavirus Crisis in the Middle East. In The COVID-19 Pandemic in the Middle and North Africa, Ed POMEPS, 10. https://pomeps.org/wp-content/uploads/2020/04/POMEPS_Studies_39_Web.pdf 
Kagurume, S. (2020). Abductions, Brutality, and Demolitions: When the State Becomes More Harmful than COVID-19.

http://democracyinafrica.org/abductions-brutality-demolitions-state-becomes-harmful -COVID-19

Kucaca, P., \& Kamga, N. (2019). Towards a Happy, Prosperous and Fulfilling Life: The Right to Development in the Zimbabwean Constitution. In Kamga, Ngang, \& Gumede (Eds.), Perspectives on the Right to Development. Pretoria: PULP.

Magaisa, A. (2020). BSR: What Exactly Did the Supreme Court Order? https://www.bigsr.co.uk/single-post/2020/05/20/BSR-What-exactly-did-the-Supreme-C ourt-order

Malaba, L. (2020). Chief Justice, Practice Directive no 1 2020; Chief Justice, Practice Directive no 2 2020; Chief Justice, Practice Directive no 3 2020; Chief Justice, Practice Directive no 4 2020. https://:zimlii.org/zw/legislation/si/2020/1

Media Institute of Southern Africa (2020). Media Institute of Southern Africa: Police Assault Freelance Journalist.

https://zimbabwe.misa.org/2020/04/12/police-assault-freelance-journalist

Ministry of Health and Child Care (2020a). Statutory Instrument-The Public Health (COVID-19 Prevention, Containment and Treatment) Regulations. Published as Statutory Instrument 77 of 2020, Consolidated as at 12 June 2020.

https://www.tralac.org/documents/resources/COVID-19/countries/3734-zimbabwe-si2020-136-public-health-COVID-19-national-lockdown-amendment-order-2020-no-10 -12-june-2020/file.html

Ministry of Health and Child Care (2020b). Daily Updates on Coronavirus Cases in Zimbabwe. http://www.mohcc.gov.zw

Moyo, G. (2016). The Curse of Military Commercialism in State Enterprises and Parastatals in Zimbabwe. Journal of Southern African Studies, 42, 351-364.

https://doi.org/10.1080/03057070.2016.1145981

Moyo, G. (2020). Obstacles and Opportunities for Financing the Fight against COVID-19 Pandemic in a Debt Trapped Zimbabwe. iBusiness, 12, 52-68.

https://doi.org/10.4236/ib.2020.122004

https://www.researchgate.net/publication/342356779_Obstacles_and_Opportunities_fo r_Financing_the_Fight_against_COVID-19_in_the_Debt_Trapped_Zimbabwe

Mutambasere, S. C. (2020). Constitutionalism in the Time of COVID-19: The Zimbabwe Experience. https://ancl-radc.org.za/node/641

Ndimande, J., \& Moyo, K. G. (2018). Zimbabwe Is Open for Business: Zimbabwe’s Foreign Policy Trajectory under Emmerson Mnangagwa. Afro-Asian Journal of Social Sciences, 9, 1-25.

https://www.researchgate.net/publication/327982537_'ZIMBABWE_IS_OPEN_FOR_B USINESS'ZIMBABWE'S_FOREIGN_POLICY_TRAJECTORY_UNDER_EMMERSO N_MNANGAGWA

Office for the Coordination of Humanitarian Affairs (OCHA) (2020). Zimbabwe Situation Report.

https://reliefweb.int/sites/reliefweb.int/files/resources/Situation\%20Report\%20-\%20Zi mbabwe\%20-\%206\%20May\%202020.pdf

Parliament of Zimbabwe (2020). Hansard. Harare: Parliament of Zimbabwe. https://www.parlzim.gov.zw/national-assembly-hansard

Pindula News (2020a). https://news.pindula.co.zw/tag/COVID-19

Pindula News (2020b). Police Block MDC MP from Distributing Mealie Meal in Her Constituency. Report. 
https://news.pindula.co.zw/2020/04/16/police-block-mdc-mp-from-distributing-mealie -meal-in-her-constituency-report

Roth, K. (2020). How Authoritarians Are Exploiting the COVID-19 Crisis to Grab Power. https://www.hrw.org/news/2020/04/03/how-authoritarians-are-exploiting-COVID-19crisis-grab-power

United Nations Human Rights Office (2020). Protection and Human Rights Considerations: Preparedness and Response to COVID-19 for South Sudan. Geneva: United Nations Human Rights Office.

https://www.globalprotectioncluster.org/wp-content/uploads/Human-Rights-and-Prot ection-Considerations-COVID-19.pdf

Veritas (2020a). Election Watch 1 Suspension of Election Activities.

http://www.veritaszim.net/node/4168

Veritas (2020b). BILL WATCH 42/2020 More MDC-T Recalls \& Two More Bills Sent to Senate. http://www.veritaszim.net/node/4278

Veritas (2020c). COURT WATCH 9/2020. http://www.veritaszim.net/courtwatch

World Health Organisation (2020). WHO Director-General's Opening Remarks at the Media Briefing on Covid-19. World Health Organisation.

https://www.who.int/dg/speeches/detail/who-director-general-s-opening-remarks-at-t he-media-briefing-on-covid-19---11-march-20

Youngs, R., \& Panculidze, E. (2020). Global Democracy and COVID-19: Upgrading International Support. IDEA, 2020.

https://www.idea.int/publications/catalogue/global-democracy-covid-19-upgrading-inter national-support

Zimbabwe Election Support Network (2020). How to Conduct Elections. http://kubatana.net/source/zesn

ZIMCODD (2020). Zimbabwe COVID-19 Response Mechanism: The Resource Factor. Harare: ZIMCODD.

http://zimcodd.org/wp-content/uploads/2020/04/COVID-19-Response-Mechanism.pdf 